\title{
PRESERVATION OF VILLAGES CONSTRUCTED ON SLIDING AREAS - A CASE STUDY FROM KARDITSA PREFECTURE, GREECE
}

\author{
Loupasakis C. ${ }^{1}$, and Karfakis $\mathbf{J}^{1}$ \\ ${ }^{1}$ Institute of Geology and Mineral Exploration, Engineering Geology Department, Messoghion, \\ Avenue 70,11527,.Athens, Greece,cloupas@igme.gr,johnkarfakis@igme.gr
}

\begin{abstract}
The mountainous areas of the Greek dominion are occupied by many occasionally inhabitable villages that were deserted because of the fact that they were founded on areas affected by landslides. Many of those villages, during the last years, were reconstructed and their houses were turned into occasionally inhabitable country houses.

The proposed support and protection measures for the reconstruction of those villages must follow the rules of the rational management of the financial sources. The construction of expensive retaining structures in order to protect deserted houses or building sites of insignificant value is inexcusable.

In those cases the geological studies must precede all reconstruction activities. Those studies can provide detailed guide-lines in order to prevent the reactivation of the landslides and/or to reduce the implications in case of reactivation. Also, the geological studies can determine the necessary combination of the protection and support measures capable to block the preparatory and the triggering causal factors of the sliding movements. This way, the cost of the applied measures reduces to acceptable levels, compatible to the occasional use of those villages.

Petroxori village (Argithea district, Karditsa prefecture) is a typical example of a village constructed on an unstable area that generated several geotechnical problems. The evaluation of those problems and the presentation of the proposed measures can be a useful reference for the confrontation of similar situations.
\end{abstract}

Key words: Rotational slides, occasionally inhabitable villages, Petroxori, Argithea.

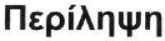

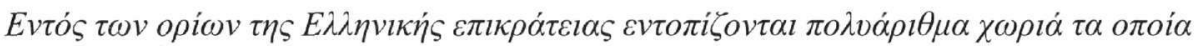

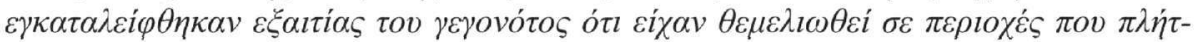

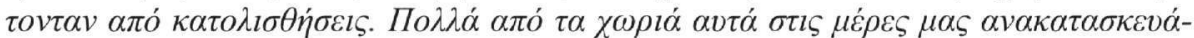

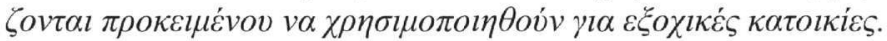

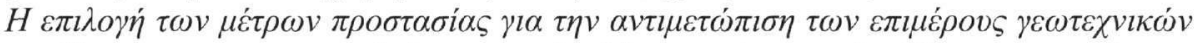

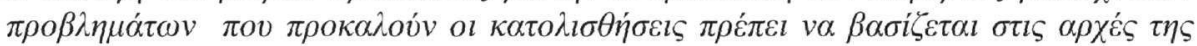

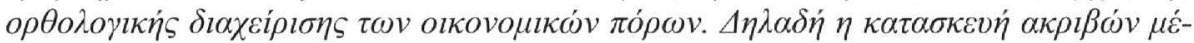

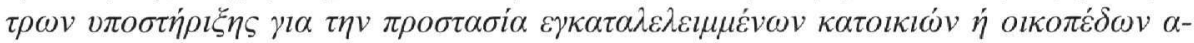

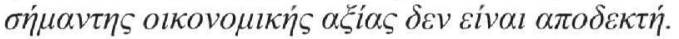




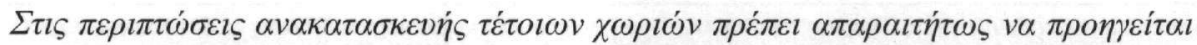

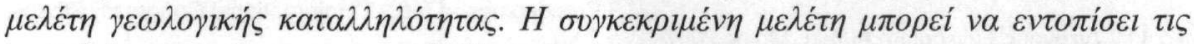

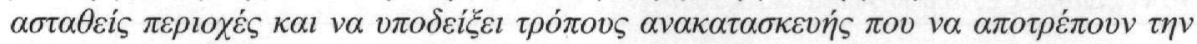

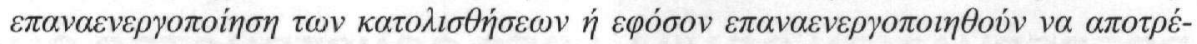

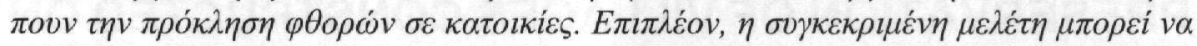

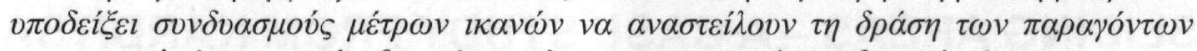

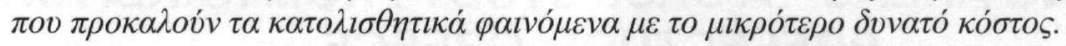

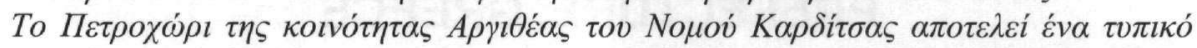

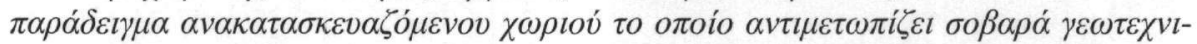

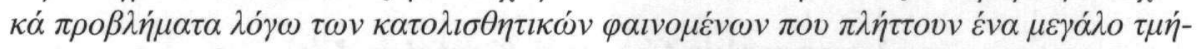

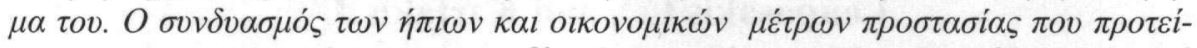

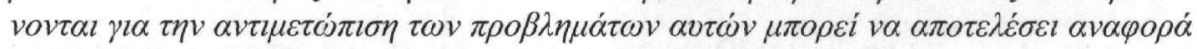

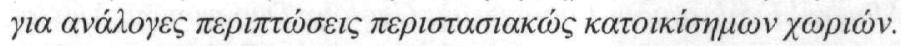

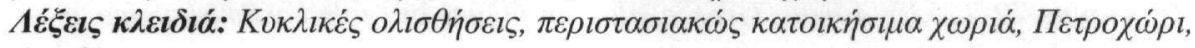
Ap $\imath_{\imath} \theta \dot{\varepsilon} \alpha$.

\section{Introduction}

The mountainous areas of the Greek dominion are occupied by many occasionally inhabitable villages. A grate number of those villages were deserted because of the serious geotechnical problems had been occurring due to the fact that they were founded on areas affected by landslides.

The first residents, mainly cattle-breeders, of those mountainous villages chose their locations based on the existence of spring water and of small arable areas. The areas covering those needs most of the times are occupied by flysch or neogene formations, or by debris materials. Those formations combined with the intensive rainfalls and the man-made processes are connected with the $80 \%$ of the landslides occurring in Greece (Koukis et.al. 2005).

Many of those villages have been deserted for several decades but, despite the geotechnical problems, during the last years their houses were reconstructed and turned into occasionally inhabitable country houses, activated only during the spring or the summer holidays. The reconstruction of those villages brought to the front the geotechnical problems and forced the local authorities to search for solutions.

Those geotechnical problems can not be confronted by applying expensive techniques similar to those applied for the stabilisation of sliding areas affecting national roads, cities or permanently inhabitable villages. On the contrary, the reconstruction of those villages must follow specific rules in order to avoid the reactivation of the landslides and/or to reduce the implications in case of reactivation. That way, the cost of the protection and the stabilisation measures reduces to acceptable levels, compatible to the occasional use of those villages.

Petroxori is a village located at the mountainous areas of Karditsa prefecture within the administrative limits of Argithea district. Petroxori is a typical example of a village constructed on an unstable area that generated several geotechnical problems. Those problems, combined with socioeconomic criteria, stopped the development of the village. During the last decade the village was partly reconstructed, but the reactivation of the sliding area generated several problems. The evaluation of those problems and the presentation of the proposed measures can be a useful reference for the confrontation of similar situations.

\section{Geomorphological and geological settings}

Petroxori village is constructed on the east slope of Karaves hill (south Pindos) on an altitude of $1100 \mathrm{~m}$. The dip angles of the slopes at the proximity of the village are $40^{\circ}$ to $50^{\circ}$ (Fig. 1). Because of the intensive inclination of the slopes, the area occupied by the village was formed in terraces. 
The village was founded on the formations of geotectonic zone of Pindos. To be more precise the south-western part of the village was founded on the upper Cretaceous limestones, the northeastern part was founded on the flysch and on the transition layers to the flysch formation and the central part on debris materials (I.G.M.E. 1993).

The transition layers to the flysch formation constitute the passage of the upper Cretaceous limestones towards the flysch and they consist of platy limestones, sandstones and argilaceous schists alternations. The limestones predominate in the lower and the sandstones in the upper members. The debris materials are products of the tectonic fracturing and the erosion of the before mentioned bedding formations and, concerning their grain distribution, they can be characterised as sandy clays with gravels.

In general, Pindos zone formations are characterized by an extremely complicated structure. They appear highly folded in a series of anticlines and synclines, interrupted and displaced by fracturing and faulting. Particularly, at the center of the village, the flysch formation occupies the core of a syncline structure with an axis of N.NW-S.SE direction and a plunge towards N.NW. Both, the eastern and western limbs of this syncline are occupied by the transition to the flysch

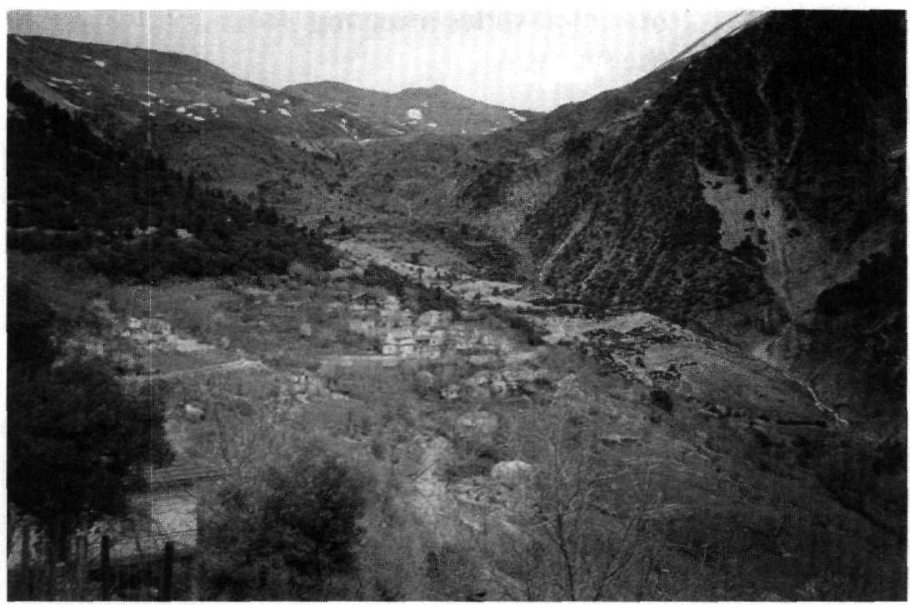

Figure 1 - A panoramic view of the Petroxori village

formation, as well as, by upper Cretaceous limestones. The western limb of the Petroxori syncline was thrusted with impulse from the east to the west over a parallel syncline with a core composed, mainly, by layers belonging to the transition to the flysch formation. The western limb verges towards the east with an angle of $45^{\circ}$ to $60^{\circ}$. The above described tectonic structures are interrupted by faults of NE-SW direction.

\section{Geotechnical settings - Distribution of the Failures}

According to bibliographical data Petroxori was damaged by landslides several times (Eleftheriou and Mougiaris 1980). Those phenomena were examined for the first time on 1957, but since then reactivations were reported on 1963, on 1980 and finally on 2006.

From the inspection of the village and from the bibliographical data came out that in all cases the surface raptures were located into the areas occupied by the debris materials. On the contrary, no failures were reported into the areas occupied by the limestone, the flysch or the transition layers.

Based on their mechanism, those landslides can be characterized as rotational slides (Varnes 1978) (Fig. 2). They act independently, affecting the terraces, and although they all have the same preparatory causal factors, each one was activated independently.

According to the WP/WLI reporting method (1994), the main preparatory causal factors of those failures are, regarding the ground conditions, the existence of plastic weak material and, regarding the man made processes, the construction of the terraces (Excavation of slope). Note that, the debris materials, as products coming from the erosion of the flysch and the transitional formations, appear high contents of clay materials. 


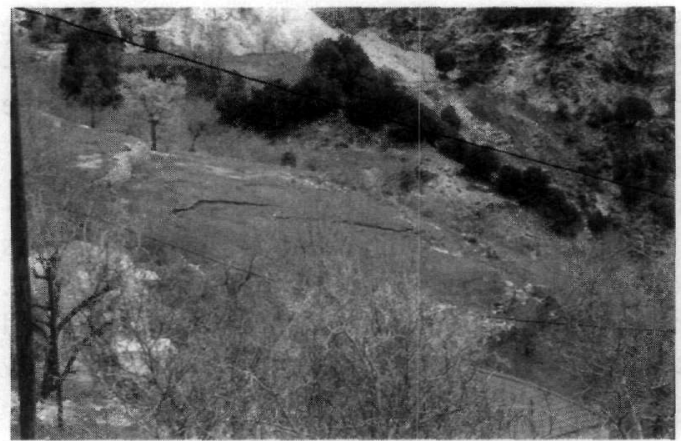

Figure 2 - Rotational slides affecting the terraces

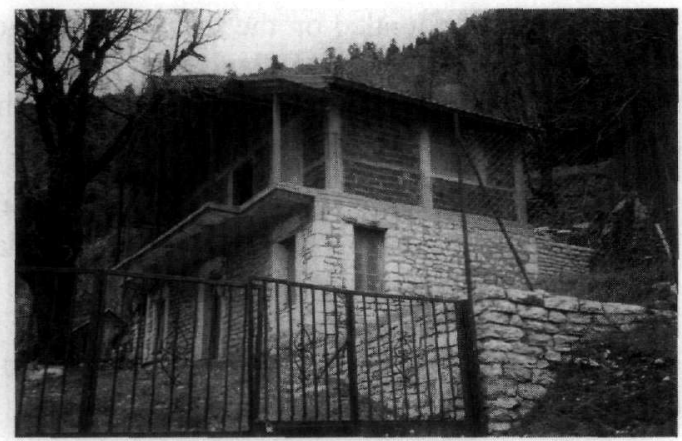

Figure 3 - Reconstruction and extension of an old house

According to the same reporting method (WP/WLI 1994), the triggering causal factors of those landslides are, regarding the physical processes, the prolonged high precipitation and, regarding the man made processes, the loading of slopes or their crests and the uncontrolled flow of the surface water through the village (natural irrigation and water leakage from services). The loading of the slope was succeeded by the construction and lately the reconstruction and the extension of buildings (Fig. 3) and the uncontrolled flow of the surface water through the village (Fig. 4) was caused by lack of drainage network.

Each failure was triggered by a different combination of triggering causal factors. Except from the prolonged high precipitation that affected all the slopes, all the other factors acted in relation to the local conditions of each slope. For example, the slope presented in figure 5 failed during a year of prolonged high precipitation (2006) because of the increasing loading of its crest caused by the reconstruction and the extension of the house. On the contrary, the slope presented in figure 2, although it is completely unloaded, failed because of the excessive natural irrigation caused by the uncontrolled flow of surface water through the field.

Figure 1 proves that those phenomena were well understood by the old residents of the village, because, despite their initial attempts (Fig. 6), they finally stopped constructing buildings along the zone occupied by the debris materials. In that picture is clearly presented that the majority of the houses were constructed on the north-eastern and the south-western parts of the village; occupied by the flysch formations and the limestones, respectively. On the contrary, the central section of the village was finally used for

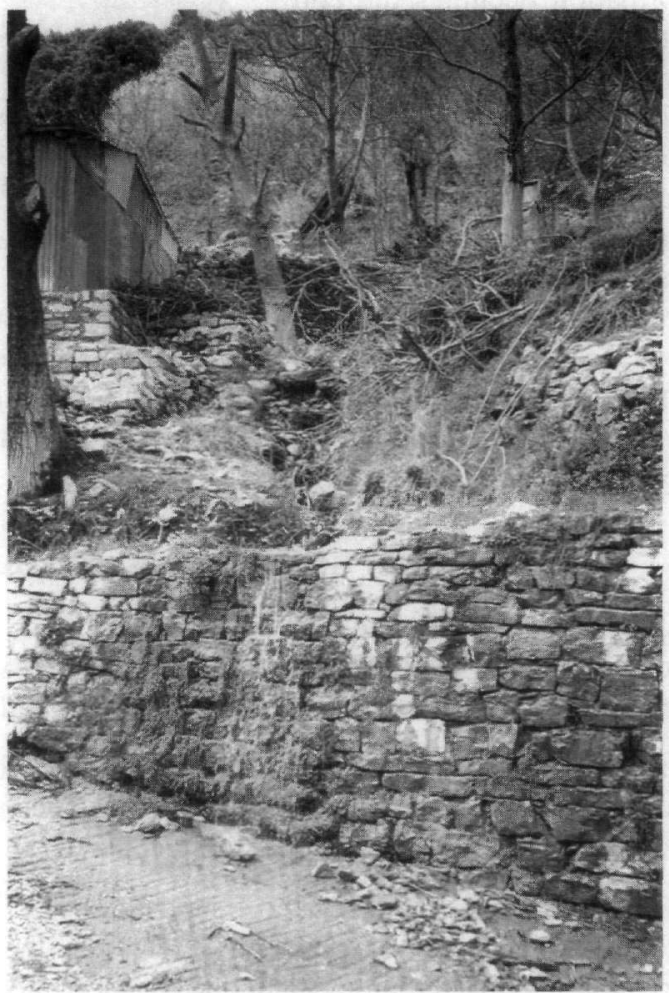

Figure 4 - Uncontrolled flow of the surface water through the village cultivation. However, the latest owners of the properties ignored the experience of the past and reconstructed houses on the unstable areas (Fig. 5). 


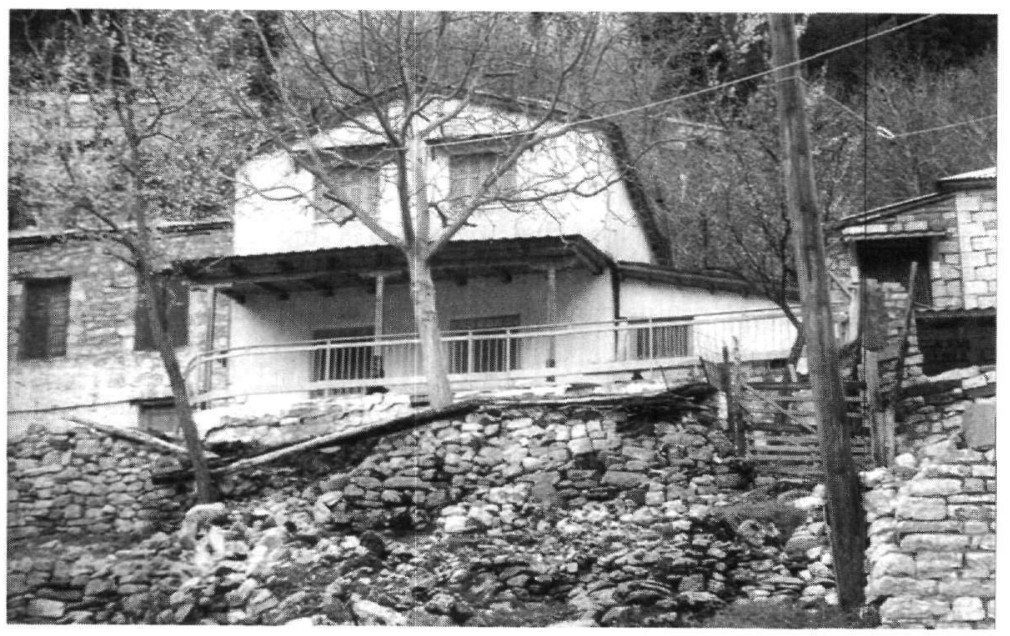

Figure 5 - A typical example of slope that failed during a year with prolonged high precipitation because of the increased loading of its crest. The landslide caused extended damages to the house

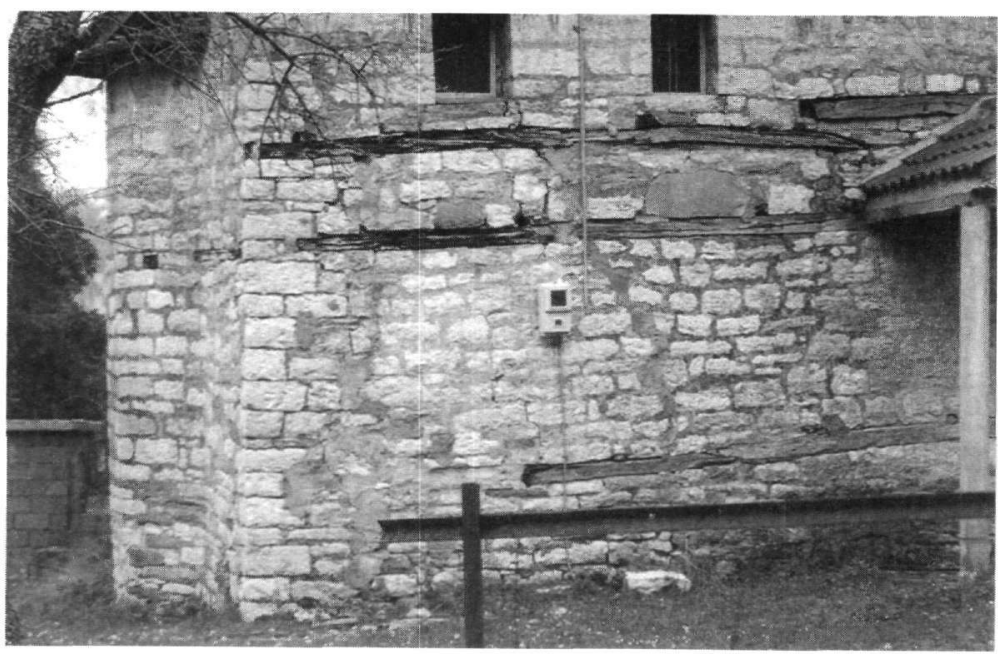

Figure 6 - Old damages on the church of saint Paraskevy caused by surface raptures. The church was founded on the debris materials

\section{Proposed measures}

The fact that Petroxori is an occasionally inhabitable village, partly reconstructed and without public service facilities (schools, health centres, etc.) actually determined the cost/efficiency relationship of the proposed support and protection measures. The proposed measures aim to reduce the influence of the landslides on the constructions and to allow the uninterrupted development of the village without proposing inexcusably expensive retaining constructions. Actually, the proposed measures aim to reduce the consequences of the oncoming movements, expected to happen during periods of prolonged high precipitation. The proposed measures were set out as follows (Karfakis and Loupasakis 2006). 
- Reconstruction of the retaining walls of the terraces by using gabions. Gabion walls are flexible and they can take over considerable deformations caused by foundation's settlement or by sliding movements without failing. Note that, the old dry stone retaining walls of the terraces deteriorate intensively when deserted. So, the majority of them require reconstruction.

- Construction of surface drains in order to divert water from flowing onto the sliding area (collecting ditches and pipes). Note that, because of the morphology the majority of the surface water precipitating within the limits of the village flows through the sliding area. So the construction of surface drains can reduce the effects of the main triggering causal factor, the prolonged high precipitation.

- Asphalt or concert paving of the roads. The drain network of the roads must be connected with the proposed surface drains extending all over the village. By means of that procedure the roads can work as horizontal barriers of the flowing water and they can help towards the wiser organising of the drain network.

- Prohibition of the extension of buildings. The construction of additional floors increases the loads of the slopes' crests and triggers the ruptures. Note that, at the moment, those phenomena are confined within the limits of the debris materials. But because of the poor mechanical characteristics of the flysch and the unfavourable dip direction of the limestones' bedding the construction of additional floors must be reconsider all over the village. Further more, the owners of the houses founded along the debris materials must be informed for the unstable conditions of the area in order to prevent them from reconstructing their houses. In those cases it is better to exchange their building sites with other sites, provided by the state, in one of the stable sections of the village.

- Tree planting of the terraces. The root strength mechanical effect combined with the gabion walls can reduce, or even more efface, the surface raptures occurrence in the majority of the terraces.

- Prohibition of the cultivation of plants requiring big amounts of water for irrigation. Note that, because of the occasional habitation of the village the residents do not cultivate any plants at the moment. Despite that, they must be informed for the consequences of the irrigation of the slopes.

It is obvious that, the before mentioned support and protection measures can reduce the surface raptures but they can not prevent them from happening. Despite that the debris materials area divides the village in the middle, the failures' very slow rate of movement (WP/WLI 1995) and their occasional reactivation (WP/WLI 1993), reconcile with the occasional habitation of the village. The consequences of the raptures (e.g. small displacements along the road network), as far as they do not affect the buildings, they can be easily repaired before the next spring season. Note that, in cases of villages permanently inhabitable the fact that the unstable area can divide the village in two sections is unacceptable.

\section{Conclusions}

The reconstruction of deserted villages founded on areas affected by sliding movements, in order to become occasionally inhabitable country houses, must follow the rules of the rational management of the financial sources. The construction of expensive retaining structures in order to protect deserted houses or building sites of insignificant value is inexcusable.

In those cases the geological studies must precede all reconstruction activities. Those studies can provide detailed guide-lines in order to prevent the reactivation of the landslides and/or to reduce the implications in case of reactivation. Also, the geological studies can determine the necessary combination of the protection and support measures capable to block the preparatory and the 
triggering causal factors of the sliding movements. This way, the cost of the applied measures reduces to acceptable levels, compatible to the occasional use of those villages.

\section{References}

Eleptheriou, An., and Mougiaris N., 1980. Geotechnical study of the sliding built up areas of the Argithea district of Karditsa Prefecture, Institute of Geology and Mineral Exploration, Report, 52pp.

I.G.M.E., 1993. Geological map of Greece, Mouzaki Sheet (scale 1:50.000), Athens, I.G.M.E. Publications.

Koukis, G., Sabatakakis, N., Nikolaou, N., and Loupasakis, C., 2005. Landslide hazard zonation in Greece. In K. Sassa, H. Fukuoka, F. Wang and G. Wang (eds), Proceedings of open symposium on landslide risk analysis and sustainable disaster management in the First General Assembly of International Consortium on Landslides, Springer-Verlag, Berlin, 291-296pp.

Karfakis, J., and Loupasakis, C., 2006. Engineering geological study of the landslides occurring at Petroxori village of Argithea district, Karditsa Prefecture, Institute of Geology and Mineral Exploration, Report, 44pp.

Varnes, D.J., 1978. Slope Movement Types and Processes. In: Schuster RL, Krizek RJ (eds). Landslides: Analysis and Control, Special Report 176, Transportation Research Board, National Academy of Sciences, Washington, 11-33pp.

WP/WLI (International Geotechnical Societies' UNESCO Working Party on World Landslide Inventory), 1993. A suggested method for describing the activity of a landslide, Bulletin of the International Association of Engineering Geology, 47, 53-57.

WP/WLI (International Geotechnical Societies' UNESCO Working Party on World Landslide Inventory), 1994. A suggested method for reporting landslides causes, Bulletin of the International Association of Engineering Geology. 50, 71-74.

WP/WLI (International Geotechnical Societies' UNESCO Working Party on World Landslide Inventory), 1995. A suggested method for describing the rate of movement of a landslide, Bulletin of the International Association of Engineering Geology, 52, 75-78. 